\title{
eLyra
}

\section{Reescrever é desfazer tranças}

\author{
Susanna Busato \\ Universidade Estadual Paulista - UNESP \\ São José do Rio Preto/SP-Brasil
}

Resumo: Escrever é sempre reescrever ou reinscrever o outro no texto que se tece. Um exercício de alteridade constante. Procura-se aqui focalizar esse exercício tendo a poesia como guia para uma leitura do conto de fadas, como um exercício de reescritura como performance crítica da própria escrita. Este artigo pretende apresentar uma reflexão analítica de duas narrativas para crianças, de Ana Maria Machado e de Chico Buarque de Holanda.

Palavras-chave: reescrita, conto de fadas, Ana Maria Machado, Chico Buarque de Holanda

Abstract: Writing is always to rewrite or re-write the other in the text that is being constructed. It is an exercise of constant alterity. The aim of this article is to focus on this task, with poetry as a guide for reading the fairy tales, as an exercise in rewriting as a critical performance of the writing itself. This article intends to present an analytical reflection of two narratives for children, by Ana Maria Machado and Chico Buarque de Holanda.

Keywords: rewriting, fairy tale, Ana Maria Machado, Chico Buarque de Holanda 


\author{
Uma trança desfaz-se: \\ as mãos buscam o fundo \\ da rede inesgotável \\ anulando a trama \\ e a forma. \\ Orides Fontela \\ A imaginação, como a \\ inteligência ou a sensibilidade, \\ ou é cultivada, ou se atrofia.
}

Jacqueline Held

\title{
Reescrever é desfazer tranças
}

Um texto se fia e mira, naquele que o tece, sua arte de perder-se no tramado. A poesia é uma "ritualização da linguagem", como define Zumthor (2014: 47). Nesse rito, a performance da escrita poética adere a uma prática que "se situa no prolongamento de um esforço primordial para emancipar a linguagem" (idem: 50) de um tempo finito (que Zumthor nomeia como "biológico"). A ação de "emancipar a linguagem" está ligada a uma consciência de sua realidade, como um ser verbal e plástico, catalizador da cultura da qual nasce e reverberador de vozes que acabam se fazendo ouvir de dentro da linguagem, esse ser movediço que dá vida às palavras e as lança para o território da escritura. É a percepção dessa realidade que nos guia a compreender a ação de reescrever como um ritualizar constante da linguagem, com a qual aprendemos e apreendemos sua existência real, a do fazer-se como busca constante de si mesma. A esse ato podemos chamar, juntamente com Zumthor (idem: 51) de "performance", tomado em seu momento presente de elocução.

$\mathrm{O}$ ato de (re)escrever, eu diria, é o de traçar a cada fio desfeito do texto possível a trança que novamente se cria: a da história daquele que tece, ou da história em que é tecido. Eu diria que há sempre uma narrativa outra no caminhar desse fio. O poema de Orides Fontela, de seu livro Transposição, nos informa esse caminho paradoxal da escrita, que ao fazer-se, destruindo o caminho, aponta para um antes que é o das mãos que tecem, o sujeito que trama, e que está lá na ausência do real que se mostra: o desfazer como que 
reaprender-se. Eis a performance da escrita que aponta para a reescrita como ação que abole o tempo finito e insere na ação do fazer-se a produção mimética do próprio ato. Uma poesia que aponta para a mimese de si própria no momento do fazer-se. Uma poesia, de outro modo, cuja ideia de escritura estaria na ideia do desfazimento.

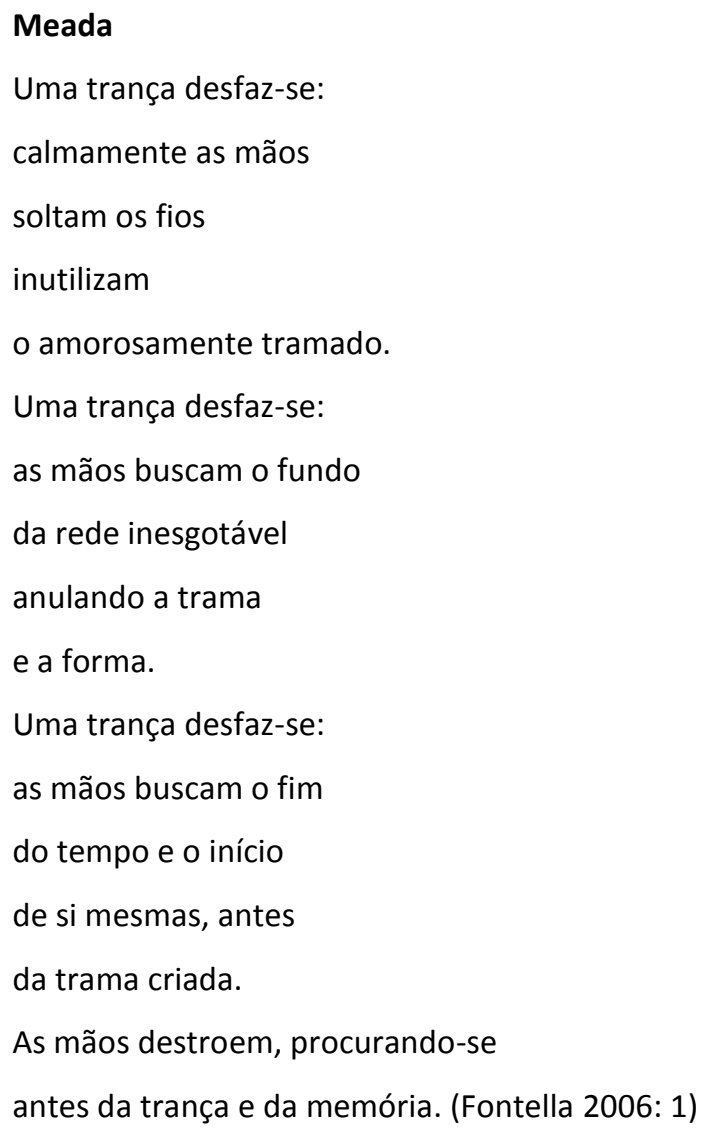

Destrançar a trama pelas mãos que outrora a fizeram é alçar a trama num antes do corpo, pura memória que avança a um tempo primordial. É um buscar, por essa linha que trama o poema, a própria linguagem, seu ser inaugural. Seria, também, retardar o fim, tornando-o início a cada retorno da trama. Lembremo-nos de Penélope a trançar o tapete durante o dia e a desmanchá-lo durante a noite enquanto aguarda seu Ulisses retornar da guerra e evitar que os seus pretendentes a desposem. Seu amor e fidelidade a Ulisses a faz tecer e retecer o texto finito no sem fim do ato do tecer, a narrativa em curvas da espera e da memória do marido. Também a atitude de Sherazade que narra todas as noites um conto para escapar da morte estaria construindo esse texto mosaico que se mescla a retornos e se entretece (entretém o outro na sua rede) de tramas que prendem o outro. 
A ideia de reescrita, no contexto que alinho aqui, estaria inserida, de modo geral, na ideia de construção contínua (e infinita) de um único texto, assim hipoteticamente considerado, cujos fios se teceriam em ramificações de raízes de outros textos, como se cada texto fosse a "tradução" do outro, em vários níveis, até perdermos a noção de origem, da qual, órfãos, seríamos condenados a tecer eternamente os caminhos de retorno (as saídas do labirinto), e daí respiraríamos somente pelos poros do texto, de onde se veria e se perceberia seu aqui e agora, seu real inapreensível. Um lance de dados, sem dúvida, que a cada "jogada" se vê transformado em uma outra constelação.

Parto aqui do exemplo das narrativas dos contos de fadas que se popularizaram com o tempo e refletem justamente esse fio contínuo que se bifurca em outros tantos. A origem dos contos de fadas é incerta, mas tem seu lugar nas tradições orais que remontam bem antes da Idade Média. A sistematização de sua presença para nós deu-se com a preocupação de escrevê-las e compilá-las em livro. Esse formato daria aos contos uma presença diferenciada e seria objeto de instrução, didatismo e consumo em novo suporte. Um exemplo significativo, e que data do século XIX, é o dos irmãos Grimm, que popularizaram esses contos, reescrevendo-os em sua procura por dar um formato literário aos contos populares de tradição oral. Tais contos não prescindem do encantamento, mas também não se esquecem da moral que lhe está subjacente. Um exemplo é o conto Branca de Neve, que foi submetido a duas versões pelos irmãos Grimm, em 1812 e 1815, e em cujas obras popularizaram essas histórias tornando-as objeto de leitura das crianças. Não podemos nos esquecer de que o conto Branca de Neve (cuja origem é incerta) estaria inserido já na narrativa de A Jovem Escrava (1634), de Giambattista Basile, que escreveu o conto em dialeto napolitano a partir da tradição oral.

O que nos interessa nesse terreno da reescritura é justamente evidenciar a linguagem da poesia como o lugar encantatório desse universo, responsável por construir o lúdico nos contos de fadas como um espaço reivindicatório da mudança de perspectiva muitas vezes. Algo nessa linha podemos entrever na narrativa de Sherk!, do escritor norteamericano William Steig, cujo conto tornou-se uma série cinematográfica de animação de grande sucesso. Publicado originalmente em livro, em 1990, o conto Shrek! (em alemão, "terror", algo como uma onomatopeia para expressão do pavor) conta a história de um 
herói que sai de casa, viaja o mundo e recebe de uma feiticeira o seu destino de encontrar sua princesa e casar-se com ela. Mas isso não acontece facilmente, pois o herói tem de viver suas peripécias e, por fim, lutar contra um cavaleiro armado na entrada do castelo que guarda sua princesa. Até aqui nada de mais, apenas uma história com uma estrutura familiar ao leitor de contos de fadas, se não fosse por um detalhe: o herói é um ogro! Normalmente, aos ogros são destinados outros papéis, mas até os brutos amam e o herói Shrek segue sua sina ditada pelos contos de fadas.

A narrativa em prosa conta o destino de Shrek. Será no encontro com a princesa, entretanto, que a linguagem da poesia irá encerrar todo o humor e encantamento desse par tão bizarro na sua aparência e troca de carinhos. Os diálogos serão travados por meio da quadra em versos redondilhos maiores, ao gosto popular, com rimas alternadas, na tradução para o português, e no original em inglês, os versos metrificados seguem esquemas diferentes a cada par de quadras, assim como as rimas, que seguem emparelhadas. De qualquer forma, o mecanismo dos versos obtém algo além do mero diálogo; transforma o encontro entre os personagens numa bem-humorada disputa de elogios, na qual o leitor, se quiser, poderá entrar, pois o jogo montado parece seduzir a criatividade para com o universo da linguagem. O que poderia ser mero xingamento, as crianças sabem compreender na história, por meio da poesia, que o encantório da história subverte esse conhecimento primeiro da língua para promover o nível segundo de seu uso.

\footnotetext{
Said Shrek: "Your horny warts, your rosy wens, Like slimy bogs and fusty fens, Thrill me."

Said the princess: "Your lumpy nose, your pointy head, Your wicked eyes, so livid red, Just kill me". (Steig 2008: s.p.)
}

[Disse Shrek: "Tuas verrugas cascudas, tuas espinhas sebentas, / Me encantam mais que as poças mais lamacentas." Disse a princesa: "Tua cabeça pontuda e teu nariz melequento / Me enfeitiçam mais que o sapo mais purulento." (Steig 2010: s.p., tradução original de Eduardo Brandão)] 
O universo amoroso entre Shrek e sua princesa é o tão esperado desenlace em casamento. É aí que a narrativa de Steig intensifica a mudança de perspectiva, já iniciada com a escolha de um ogro para o papel do herói. O diálogo amoroso acentua a identidade dos dois protagonistas e constrói um universo paralelo de elogios bizarros de um a outro. 0 lúdico instaura-se pela performance dos personagens que, pelo discurso direto, encenam o amor por meio de expressões do universo do grotesco, subvertendo o sentido das palavras, ou melhor, fornecendo para nós, leitores, uma naturalidade e beleza que aceitamos como num jogo. Na tradução de Eduardo Brandão para o livro, temos uma adequação do sentido ao nosso idioma e cultura:

Disse Shrek: 'Oh, que horrorosa tu és

Com teus lábios azuis,

Teus olhos inchados

Parecem cheios de pus!

Tu já sabes que te amo

E sabes até por quê,

É que não haverá neste mundo

Princesa mais feia que vosmecê!'

Disse a princesa: 'Teu nariz é tão peludo,

Como tu és bexiguento!

A nossa história tem tudo

Para acabar em casamento!' (Steig 2010: s.p.)

A figura que me surge no contexto do movimento da reescritura é a da espiral, em cujas voltas e curvas aproximamo-nos e distanciamo-nos dos demais textos, como que a tocá-los de quando em quando em suas curvas, também em movimento, para o pensamento que as atravessa. Talvez a ilusão dessa figura ligada à ideia de infinito estivesse geometricamente determinada pela fita de Möbius, criada em 1858 pelo matemático alemão August Ferdinand Möbius. A indeterminação de suas faces (ou de seu espaço) perturba e engloba num contexto único o fora e o dentro, o em cima e o embaixo. O não saber de onde vêm as direções, tampouco para onde vão (a fita como um objeto não 
orientável) talvez seja uma imagem aproximada do que seja o movimento da reescritura, cujos fios de texto avançam para o texto de partida (por sua vez construído por outros), mas dele se distanciam no desfazimento de suas tramas, para aí inserir outros textos e discursos, a ponto de não sabermos exatamente, salvo uma rigorosa análise (mesmo assim não finalizadora), de onde nascem. O exemplo anteriormente oferecido no contexto dos contos de fadas pode ilustrar o que pretendo. Eis, portanto, a questão das referências do texto e de suas intersecções na trama a provocar o leitor e a fazê-lo pensar e recriar (por que não?) o texto que tem diante do olhar. Afinal, toda leitura é um exercício de reescritura. Veremos que a literatura para crianças acumulou ao modo de um palimpsesto as narrativas e seus personagens e o processo de reescrita dessas histórias acabou formulando novos contos de fadas que reúnem em constelação as referências às narrativas clássicas, inovando em sua forma e linguagem.

Roland Barthes (2004), em O Rumor da Língua, já desfiara a noção de texto e nos levara justamente para a sua natureza lúdica, declarando que "o seu campo é o do significante" e que sua lógica é metonímica, uma vez que se faz a partir de um "trabalho das associações, das contiguidades, das remissões", configurando um "sistema sem fim nem centro" (Barthes 2004: 69). Para nos ajudar em nosso raciocínio, recolho ainda o que o semiologista francês aponta como essencial para a compreensão da ideia de texto: ser não a "coexistência de sentidos, mas passagem, travessia", sendo pois plural na sua estrutura, exigindo também um leitor caminhante que se detenha a cada pisada. Um texto, portanto, que se faz por uma rede tecida de diferenças: "de citações, de referências, de ecos: linguagens culturais (que linguagem não o seria?), antecedentes ou contemporâneas, que o atravessam de fora a fora numa vasta estereofonia" (idem: 71). Considerando a natureza assim descrita do texto, a cada vez que escrevo há um outro que também fala e que se ouve naquilo que escrevo, e que veio antes, ou que alude ao que virá porventura. Um texto é memória de outro que se presentifica como um eu (um "je suis un autre", para me lembrar desse sujeito que fala no texto a língua que não lhe pertence e da qual faz sua no momento em que se transforma em linguagem). Novamente Barthes:

O intertextual em que é tomado todo texto, pois ele próprio é o entretexto de outro texto, não pode confundir-se com alguma origem do texto: buscar as "fontes", as "influências" de uma obra é 
satisfazer ao mito da filiação; as citações de que é feito um texto são anônimas, indiscerníveis e, no entanto, já lidas: são citações sem aspas. (ibidem)

Conhecer um texto é caminhar em suas tramas, ser surpreendido aqui e ali por uma pedra deixada no meio do caminho, para que possamos aprender com ela os caminhos anônimos do texto. Ler é traduzir, é transpor o texto para uma experiência de repertório que nos dará os roteiros possíveis de outros textos. A poesia irá tramar com sua fina agulha aquilo que torna o texto encantado: sua palavra como o lugar do humor, da transcriação, da superação da prosa pelo discurso da imaginação além da referência, ou seja, por mecanismos linguístico-sonoros, linguístico-visuais, tecidos na urdidura da palavra: paradigma de emancipação da leitura e iluminadora de um pensar a linguagem como espaço crítico de criação.

\section{Reescrever é olhar para dentro do texto}

A narrativa contemporânea destinada ao público infantil revela-se atenta ao repertório das histórias do gênero e à necessidade de constante adaptação ao público infantil. A necessidade decorre justamente de nossa época que não mais se vê reprodutora do passado, mas revisionista e crítica dos enredos que têm sido narrados. A visão crítica da história tem descoberto outras narrativas não contadas e têm dado vez e voz a seus protagonistas. As narrativas dos sobreviventes a holocaustos e a guerras e a atrocidades cometidas por regimes ditatoriais, por exemplo, erguem-se em textos a recontar o que se ocultava ou se condenava ao silêncio. A impossibilidade do dizer foi transformada pela necessidade de dizer. Com as narrativas dos contos de fadas não tem sido diferente. Os novos meios de comunicação transformaram o modo como concebemos os valores humanos e transformaram e ampliaram nosso repertório. Os contos de fadas fornecem o imaginário e a possibilidade de sonhar outros mundos. Reforçam sobremaneira categorias de heroicidade, mas questionam seus atores: de herói e bandido, cada um tem um pouquinho. Mas para quem se é herói? Para quem se é bandido? Quem de fato é o lobo mal da história? Como o personagem infantil nas histórias lidaria com essas questões? Seria salvo por um caçador? Um príncipe? Ou organizaria sua própria vida interior diante dos conflitos e seria ele próprio o herói de sua história? 
Recontar, reescrever os contos de fadas hoje tornou-se um desafio, sem dúvida. Esse universo imaginário retorna com seus símbolos e ensinamentos e o leitor hoje se sente livre para questionar. O autor se vê desafiado a reunir em seu texto os fios dos textos que estão no universo repertoriado de seus leitores. A pergunta seria: para quê mais uma história sobre Branca de Neve, ou sobre Cinderela? Ou sobre Rapunzel? Eis que as narrativas destinadas ao público infantil, portanto, se eternizam ao explorarem o mundo dos contos de fadas para criarem não somente novos leitores dessas histórias clássicas, mas leitores que possam se ver representados como autores de sua própria vida.

Em O Menino que Olhava pra Dentro (1983), da premiadíssima escritora brasileira e uma das mais importantes do gênero da Literatura Infantil e Infantojuvenil no Brasil, Ana Maria Machado, ${ }^{1}$ a história de Lucas leva o leitor a experimentar o entretecer dos fios textuais que nos religam aos contos tradicionais pelas mãos dos contos de fada. É no universo do imaginário infantil que a narrativa busca apropriar-se de textos possíveis, criados no cotidiano da mente do menino Lucas, protagonista da história. Olhar para dentro seria uma metáfora para o voltar-se para o universo do imaginário dos textos possíveis, das aventuras sem fim, dos espaços a serem desvendados, dos sujeitos a serem vividos pelo menino. Os espaços vão se entretecendo ao longo da narrativa de modo atemporal, em relação direta com o leitor, com o material fornecido pelo momento do aqui e agora da personagem (e que é também vivido por nós): seu espaço familiar e seus objetos que dividem espaço e se misturam ao espaço virtual, vivido na imaginação. A ilustração cuidadosa de Alê Abreu consegue captar esses dois universos que são visualmente representados e nos quais o leitor se reconhece. A técnica da colagem situa-nos no contexto dos dois universos, assim como a técnica do colorido do lápis de cor a ilustrar outros momentos. Tudo parece brotar ludicamente do universo interior da personagem (que "olha pra dentro").

Reescrevendo o mundo para além dele, Lucas ilumina o universo narrativo das aventuras tão familiares em outros textos da literatura como Odisseia, de Homero; As Viagens de Gulliver, de Swift; Viagem ao Centro da Terra, Vinte Mil Léguas Submarinas, de Julio Verne; para citar algumas narrativas que foram tecidas pelo fio da imaginação de seus autores, que também olhavam para dentro... 
A narrativa de Ana Maria Machado revela-nos o intertexto como esse elemento que modula as ações da personagem e a circunscrevem como um ser de papel, muito bem concebido por meio das ilustrações da história que se valem da técnica da colagem, como mencionei, para conceber os mundos paralelos na história.

A história de Lucas leva-nos, portanto, para o universo dos contos de fadas, esse espaço em si mágico em que tudo é possível. Seduzido pelo sonho e pela fascinação das aventuras vividas em sua imaginação, Lucas, um menino que "presta muita atenção em tudo" (Machado 1983: s.p.), elabora um plano: dormir para sempre, como na história de Bela Adormecida. Seu desejo é morar na sua imaginação, como nos livros de história: "Feliz para sempre". Mas seu amigo Talento retruca e Lucas concorda: "Eu acho que para sempre é demais" (idem: s.p.).

Lucas acabou concordando: "É... Passar o resto da vida espiando pra dentro pode não ser uma boa. Mas eu podia fazer isso, digamos, durante uns cem anos. Feito a Bela Adormecida."

$[\ldots]$

Vai ser meio difícil, meu irmão. Na sua casa não tem roca, para você poder espetar o dedo num fuso e dormir cem anos. Lucas teve de concordar que não ia ser fácil. (idem: s.p.)

Seu plano é bem discutido com seu amigo, "que morava nesses lugares onde ele ia quando espiava pra dentro. Lucas nem sabia se o nome dele era esse de verdade, e gostava mesmo era de chamar o amigo de Tatá" (idem: s.p.). Abro aqui um parêntesis para sublinhar a presença dessa personagem que é explicada pelo narrador e pelo protagonista da história a partir de um relato que se debruça sobre a semântica da língua. Neste momento autora e personagem encontram-se sutilmente no discurso esclarecedor e didático, mas um didático de propensão lúdica, diga-se. Nomear é dar atributos, é uma construção de linguagem. Seu nome Talento origina-se de uma anedota: como andava muito devagar, o menino dizia: "Tá lento!". O nome, de tanto repetir, pegou: "Talento".

No começo, nem tinha nome. Mas, como ele sempre vinha com calma, sem pressa, e Lucas queria que ele andasse mais rápido, reclamava: "Tá lento, tá lento...". O amigo achava graça e continuava. Devagar e sempre. Um dia, achou graça no nome e corrigiu: “Tá lento, não. Tá manco". E Lucas ficou sem saber o que era, talvez o amigo estivesse explicando que andava devagar porque não ia lá muito bem das pernas, mancava ou tinha pouca firmeza. Ou era porque gostava de tamanco ou chinelo. 
Talvez o amigo estivesse brincando com ele, Lucas, que às vezes bem que se sentia manco, com esse negócio de viver pisando com um pé no mundo lá de fora e outro no lá de dentro. Ou então, também podia ser que o garoto estivesse explicando que o nome dele não era Talento, era Tamanco. (idem: s.p.)

O significante é exposto como matéria a ser desnudada no texto e já oferece ao leitor um conhecimento sobre a língua, a linguagem e seu uso, do qual derivam todas as coisas que podemos nomear. É pelo significante que a história acontece desde o início. Eis como a poesia, aos poucos, irá adentrar a narrativa, tornando-a puro encantamento. O universo da imaginação do personagem é concretizado pela forma tanto verbal - da narrativa em si, quanto não-verbal - a da ilustração. A natureza da personagem é feita de uma matéria de signos: palavra impressa, som, traço, cor, planos, figuras. Sua vida é a da escritura-leitura; brota de um exercício com a palavra. (Palo / Oliveira 1992: 35) Esse aspecto de concretude da natureza da personagem revela seu ser de papel que promove no leitor uma projeção: "je suis un autre", para repetir a expressão usada anteriormente aqui: "sou um outro" diria o leitor, sou esse que aí está e com o qual me identifico; também sonho e espio para dentro dos livros os sonhos de Lucas, que são meus também. Mas o exercício poético é um exercício de alteridade...

Voltando ao plano de Lucas de querer viver para sempre no mundo da imaginação, sua ideia é a de comer a maçã e engasgar-se com ela. A referência é ao conto de fadas Branca de Neve, onde a maçã é o elemento mágico que fará a protagonista dormir para sempre (maldição de sua madrasta). Seu amigo Talento ainda retruca que ele não é o Branco de Neve. Mas nada o demove do plano, e naquela noite, depois do jantar, foi mais cedo para a cama,

resolveu que o melhor era engasgar com a maçã na hora de deitar, quando estivesse sozinho. É que a família dele era tão desligada dessas coisas que era até capaz de alguém dar um tapa nas costas dele só para desengasgar, e aí estragava o plano todo. (Machado 1983: s.p.)

Observe-se nesse momento como a autora insere a história de Branca de Neve sutilmente no meio da trama do plano de Lucas, como se dele fosse esse pensamento estratégico, conhecedor ele, portanto, da história a ser imitada. O plano de viajar para 
sempre no mundo da imaginação tem um objeto mágico, a maçã, da narrativa de Branca de Neve na qual a maçã sedutora, entregue pela madrasta disfarçada de camponesa, exerce um fascínio sobre a heroína e se torna um instrumento da morte simbólica que irá afetá-la, pois dormiu um sono profundo até ser acordada por um beijo de amor. Eis o que o "para sempre" não "pegou" no plano de Lucas, pois "para sempre" seria para muito tempo mesmo... Veremos que, ao final de seu plano maravilhoso que o levou a sonhar com o mundo fantástico da imaginação, brota o cansaço, o vazio, o momento em que nada mais consegue imaginar. Fatigados, o sonho e o menino, resta apenas um escuro, o suspense final: "Ele, de um lado. / Do outro, o mundo". Teria ele se engasgado de verdade? Mas se Branca de Neve despertou depois, Lucas também voltaria de seu sono profundo. Mas qual seria o objeto mágico desta vez? Esta não é uma história de princesas... Ou seria? Eis que o mundo da imaginação, do encantamento, encontra na poesia sua fórmula de se fazer representar.

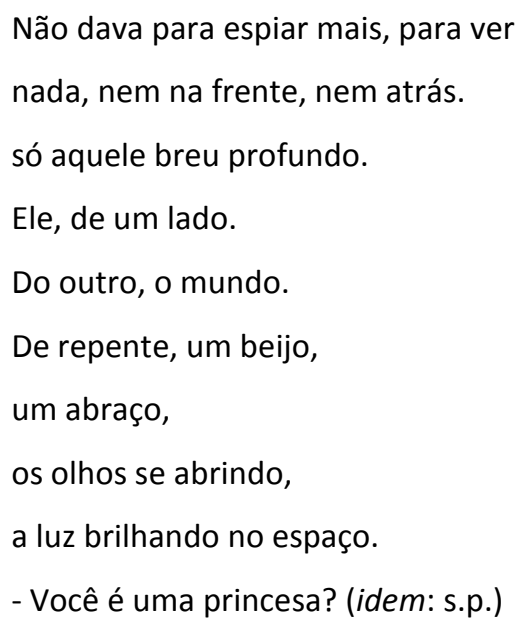

O repertório de Lucas torna-se algo a ser compartilhado por meio do jogo: o de construir um plano de viver para sempre no mundo da imaginação, nos livros de história. Podemos aqui fazer uma observação sobre a relação entre o real e o imaginário e a sedução que este exerce sobre o indivíduo. Lucas é bastante consciente da diferença entre os dois universos, tanto que deseja escolher um deles para viver, porque o percebe como mais interessante e divertido. É sua observação e percepção que o leva a escolher. Como escritor de suas próprias histórias, irá buscar nos contos de fadas os fios que o levem para esse 
universo que idealiza para consolidá-lo de fato. Antonio Candido (2002) já afirmara que toda pessoa tem direito à literatura e a desfrutar dela seus olores. Disse-o mais: toda pessoa tem necessidade de ficção e fantasia, sem isso não conseguiria conviver com a realidade. (Candido 2002) O imaginário, no conto O Menino que Olhava pra Dentro o, estaria na construção, conforme as palavras de Jacqueline Held, de uma estratégia de "esquecimento, de exorcismo e de diversão, que desvia a criança dos verdadeiros problemas do mundo de hoje e de amanhã" (Held 1980: 22). O movimento criado por Ana Maria Machado é duplo: uma assertiva à necessidade de alimentarmos o universo imaginativo da criança (e nosso também), pois nele podemos repensar o nosso próprio mundo, esse a que damos o nome de realidade. É pela linguagem que esse movimento é gerado. O intertexto construído na história é algo que irá promover no leitor mirim a identificação e o repertório. Irá, em outros termos, dar dinamismo às histórias tradicionais, como elementos a serem absorvidos para serem reconstruídos, reescritos para fazerem sentido em nosso mundo. Todo o questionamento gerado na história, por meio do diálogo entre Lucas e seu amigo Talento estaria dando ao leitor um status de legitimidade crítica, ou melhor, estaria inserindo-o como um coautor da história, que consegue também perceber o mundo ao redor e tem consciência do universo imaginário que busca; o leitor seria um outro amigo com o qual Lucas pudesse também dialogar. Esse dado é sutil e verdadeiro. O sonho de Lucas é o nosso. E ele o realiza. E como herói da história, aventura-se por nós. Sua coragem de engasgar com a maçã para poder sonhar nos assusta se levamos em conta a lógica do mundo real. $\mathrm{Na}$ lógica da narrativa, engasgar é uma performance crítica: seria viver o conto de fadas por meio de um de seus fios de história - os da Branca de Neve e os da Bela Adormecida - para poder tecer a trama da história de Lucas que está sendo contada. Eis onde o poético, então, se instaura.

A narrativa, no momento da realização do plano vai, pela linguagem, reescrever-se e incorporar o discurso da poesia no relato do sonho e das aventuras do menino, de modo a promover combinações inusitadas entre palavras ("automóveis-leões") e imagens em si que desafiam a realidade ("andou sobre as ondas"; "viu cachoeira cair pro alto"; "mergulhou fundo na terra") e que despontam de desejo ("Viu panela que não se esvazia, / viu criança 
que não se machuca) e o ritmo que acompanha as anáforas e os paralelismos sintáticos, sem deixar de lado as reverberações silábicas que tecem no plano sonoro do texto seu canto:

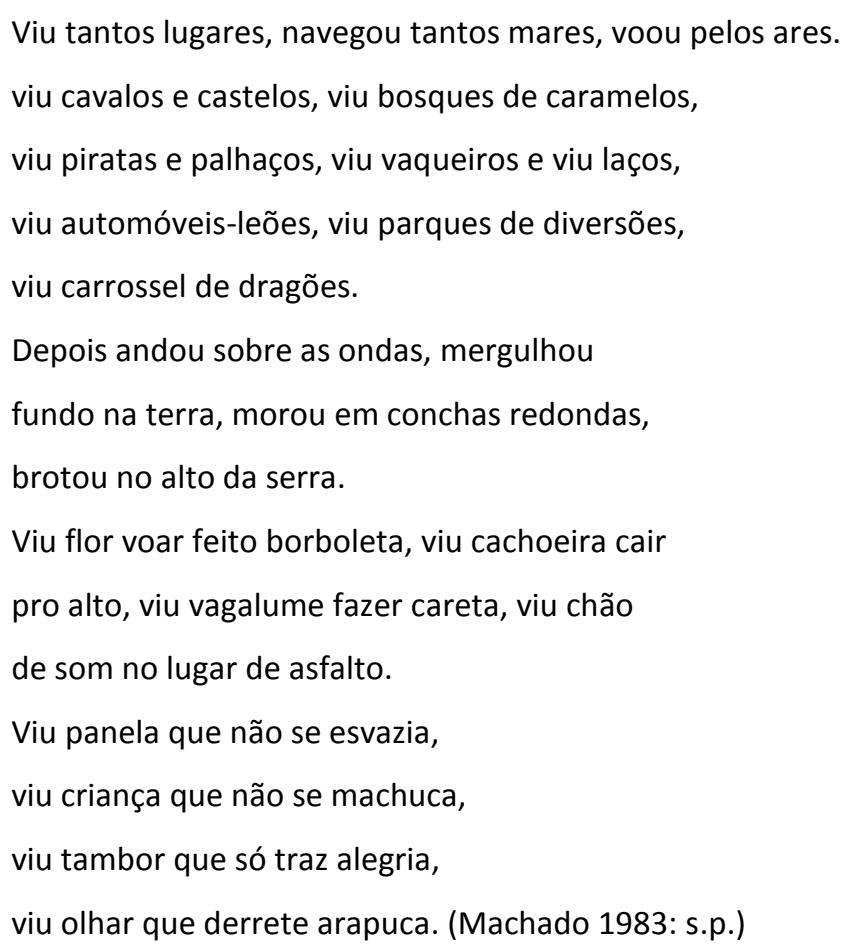

A poesia no interior do fluxo da prosa narrativa mais uma vez irá assinalar o princípio da palavra-encantamento, regida por uma lógica outra que se desvia do já-esperado e do conhecido. Ainda que Lucas utilize o elemento simbólico da maçã para adentrar o universo da imaginação, é pela poesia que a voz narradora pode fazer-nos participar da viagem do menino. Mais do que narrar a viagem, os versos tecem as tranças dos caminhos longos e tortuosos, que surpreendem a cada curva. As rimas alternadas pontuam essas chegadas e partidas, como "saltos" que a cada linha procuram um repouso breve apenas, uma vez que o ritmo pontua o caminhar constante e regular nos acentos ternários dos versos. Os enjambements acentuam os momentos de surpresa ao suspenderem a sintaxe do verso, como em: "Depois andou sobre as ondas, mergulhou / fundo na terra" e em "Viu flor voar feito borboleta, viu cachoeira cair / pro alto, viu vagalume fazer careta, viu chão / de som no lugar de asfalto".

A autora consegue, na narrativa de $O$ Menino que Olhava pra Dentro, conceber um universo da escritura como um espaço no qual os fios dos textos dos contos de fadas 
emergem em festa como condutores do pensamento da personagem e articuladores da história. O leitor familiarizado com as narrativas citadas vivencia a aventura de Lucas e participa de sua fábula. Vive, certamente, esse mundo da fantasia assim que a narrativa descreve seu plano em "tempo real". O texto de Ana Maria Machado deixa a prosa por um instante e segue pelo discurso da poesia, esta como a voz do sonho, do imaginário e do poético que encarna a viagem mágica de Lucas no seu desejo realizado.

Como vive num conto de fadas, o menino acorda com um beijo da sua "princesa": pela manhã a mãe chega a seu quarto e o acorda para ir à escola. O mundo real retorna e sua presença natural é vivida, e Lucas aprende uma coisa: que o mundo da imaginação é possível de conviver com o mundo real, cotidiano. Ganha de presente um cachorrinho de verdade, a que vai dar o nome de Tatá (apelido de Talento) e viverá com ele novas histórias com um amigo de verdade. Por um instante, poderíamos ter a sensação de que aquela noite de sonho mágico de Lucas fora o tempo de uma vivência maior, sua infância, a que a narrativa dá um tratamento poético e mítico. A história chega ao fim se referindo ao mundo real do leitor, numa cena cuja ilustração apresenta os dois amigos, a distância, brincando lá fora. Esse afastar-se da "câmera" pelo traço do ilustrador deflagra bem o final da história com um "viveram felizes para sempre". Mas "para sempre" não é demais? Não para quem consegue prosseguir com o ser criança dentro de si...

\section{Uma história devoradora}

Francisco Buarque de Holanda (Rio de Janeiro, 1944), mais conhecido como Chico Buarque, é um cantor, compositor e escritor brasileiro premiado, detentor de uma obra musical vastíssima e já repertoriada em nossa cultura brasileira. Como escritor, além de obras para o público em geral, Chico Buarque criou uma versão do clássico conto para crianças Chapeuzinho Vermelho, chamada Chapeuzinho Amarelo, de 1979, considerado um livro-poema.

A história de Chapeuzinho Amarelo é narrada em versos, bem ao gosto popular. Sabe-se que as narrativas em versos fazem parte dos chamados "romances", formas poéticas muito populares na Península Ibérica do século XV. A herança nos chegou desde cedo e persiste nos cordéis. Chico Buarque escolhe essa forma poética para nos contar essa 
pequena fábula: "Era a Chapeuzinho Amarelo. / Amarelada de medo" que "Não brincava de mais nada, / nem de amarelinha". A cor amarela vem dominar a personagem como uma interdição que se encarna nos seus dias e atividades, representada pela negação: "Já não ria. / Em festa, não aparecia. / Não subia escada / nem descia. / Não estava resfriada / mas tossia. / Ouvia conto de fada / e estremecia". As rimas sonantes em ditongo oral crescente criam no leitor um convite para o jogo poético: a ação mencionada se reverbera na seguinte, como a criar um elo sem fim de adversidades. Por exemplo: a rima foi dada no verso "Já não ria". O próximo diz: "Em festa, não aparecia". O leitor já entendeu a regra do jogo e mesmo que o narrador não complete imediatamente, estamos lá a antecipar a rima para os dois versos seguintes: "Não subia escada / nem"... descia! Sim! dirá o texto-falante do livro, muito bem, leitor! Prossiga agora: "Ouvia conto de fada / e"... "estremecia"! A mise-enscène que faço aqui é proposital, para evidenciar o lúdico da linguagem que vai envolvendo o leitor na história dessa menina, que já cria em nós uma atenção por seu comportamento tão isolado e medroso. Os paralelismos sintáticos e as anáforas percorrem a página seguinte em novos versos que intensificam no plano semântico os medos de que sofre Chapeuzinho Amarelo. Medos absurdos como "E nunca apanhava sol / porque tinha medo da sombra". Outro momento divertido para o leitor, que já vai estranhando e achando engraçada dessa menina exageradamente medrosa, é quando na série paralelística um dos versos diz: "Não tomava sopa para não ensopar. / Não tomava banho pra não descolar. / Não falava nada pra não engasgar. / Não ficava em pé com medo de cair". As explicações vão se tornando cada vez mais absurdas e criando uma sensação no leitor de que os medos parecem difíceis de ser reais.

A personagem do Lobo surge como um dos medos maiores da menina e novamente os versos vão tramando esse medo em fios tão complexos que o resultado final dessa imagem arquetípica do Lobo vai já nos oferecendo um viés para a personagem enfrentar o seu medo. A elaboração vai aos poucos se dando no interior da linguagem. Neste momento, porém, ela é de natureza reflexiva:

\footnotetext{
E de todos os medos que tinha

O medo mais que medonho

Era o medo do tal do LOBO
} 
Um LOBO que nunca se via,

Que morava lá pra longe,

Do outro lado da montanha,

Num buraco da Alemanha,

Cheio de teia de aranha,

Numa terra tão estranha,

Que vai ver que o tal do LOBO

Nem existia. (Buarque 2013: s.p.)

Percebamos no texto a reiteração da palavra "medo" e sua variante em "medonho" é importante recurso para o processo de devoração da palavra e de seu sentido. "Repetir, repetir - até ficar diferente. / Repetir é um dom do estilo", já dizia o poeta mato-grossense Manoel de Barros, no poema "Uma didática da invenção", publicado na obra O Livro das Invencionices, 1993. O poético aqui se articula com o modo como a personagem vai aos poucos se emancipando de suas fragilidades. A elaboração desse processo de libertação do medo é feito pela linguagem. No texto destacado é apresentada a reflexão sobre o medo do "LOBO", não à toa escrito em caixa alta por conta de sua presença ameaçadora. Ocorre que o tal do "LOBO", segundo a própria personagem Chapeuzinho Amarelo, era uma figura que "nunca se via / que morava lá pra longe, / do outro lado da montanha". O distanciamento marcado pelos advérbios e pela localização figurativa da "montanha", a separar a Chapeuzinho Amarelo do "LOBO", vão encontrar o tal na referência de origem - "num buraco da Alemanha" - em alusão ao país de nascimento dos irmãos Grimm, compiladores e divulgadores dos contos de fadas, notadamente o de Chapeuzinho Vermelho. A localização do tal "LOBO" vai ficando, a cada avanço dos versos, mais distante: no tal buraco ela o imagina, todo recoberto de "teia de aranha" (marca do tempo), e situado, ainda, "numa terra tão estranha", em alusão aos territórios dos contos de fadas, que ninguém sabe ao exato onde se localizam, e onde os animais e as coisas falam e fazem coisas estranhas, ou melhor, encantadas! A conclusão de Chapeuzinho Amarelo, ao final de sua reflexão é a de que "vai ver que o tal do LOBO / nem existia".

Reescrever uma história clássica como a de Chapeuzinho Vermelho para uma plateia de leitores mirins de nosso tempo requer que os paradigmas fornecidos pela narrativa de origem sejam repensados. A moral implícita na história divulgada pelos irmãos Grimm é a de 
que as meninas precisam cuidar-se e não dar ouvidos a estranhos, obedecer aos mais velhos e seguir uma vida sem desvios. Chapeuzinho Vermelho vive por um momento na história um tempo de entretenimento supostamente fútil em seu passeio pela floresta, colhendo flores, avelãs e brincando de correr atrás de borboletas. Na narrativa dos Grimm, tal momento nos fornece poeticamente pelas referências, muito mais do que pela linguagem em si, um olhar para a personagem de Chapeuzinho Vermelho como uma menina em crescimento, em fase de interessar-se pelos rapazes, de desejar satisfazer-se nos prazeres, uma vez que flores (como símbolo da delicadeza, pureza e fragilidade), avelãs (símbolo da fertilidade) e borboletas (símbolo da metamorfose). Entretanto, a trama que é composta para ela é feita de modo a que ela não seja a mestre de suas ações, mas a responsável inocente por ter dado abertura para o destino trágico de sua avó e dela própria, uma vez que o Lobo devora as duas. Salva pelo caçador na versão dos Grimm (lembremo-nos de que Charles Perrault não tem para com ela o perdão, e deixa-a morrer simplesmente ao final da história, como punição por sua suposta má conduta), Chapeuzinho Vermelho aprende a lição pelas mãos de um adulto que lhe fornece uma segunda oportunidade para "endireitar-se", a que ela, obedientemente agora e aliviada, aceita em juramento.

No caso da história de Chapeuzinho Amarelo, a personagem infantil tem em si o poder de lutar contra o mal - o medo do Lobo. Sua luta dá-se pela reflexão e pela linguagem; é de ordem intelectual e poética. Outro momento em que o dispositivo da repetição é usado é quando o narrador, muito próximo de seus pensamentos, vai construindo aos poucos a revelação da imagem do LOBO por meio da referência ao clássico diálogo do encontro entre a Chapeuzinho Vermelho e o Lobo, na casa da vovó.

\footnotetext{
E Chapeuzinho Amarelo,

de tanto pensar no LOBO,

de tanto sonhar com LOBO,

de tanto esperar o LOBO,

um dia topou com ele

que era assim:

carão de LOBO,

olhão de LOBO,

jeitão de LOBO
} 


\author{
e principalmente um bocão \\ tão grande que era capaz \\ de comer duas avós, \\ um caçador, \\ rei, princesa, \\ sete panelas de arroz \\ e um chapéu \\ de sobremesa. (idem: s.p.)
}

O processo de reescrita da clássica passagem do encontro entre Chapeuzinho e o Lobo encontra no discurso poético do autor de Chapeuzinho Amarelo o elemento de síntese, por meio do relato descritivo de como era o tal Lobo, cuja encarnação do medo é intensificada por meio da desinência do aumentativo: "carão de LOBO, / olhão de LOBO, / jeitão de LOBO". O encontro é subjetivo e psicológico. A ilustração de Ziraldo propõe esse imaginário ao justapor Chapeuzinho Amarelo (de vestidinho vermelho, numa alusão à personagem dos Grimm) ao Lobo, para o qual olha bem curiosa e atenta, enquanto ele a enfrenta com seu focinho voraz e ameaçador. Não há medo no olhar da menina, que parece na verdade olhar para uma imagem. Esse aspecto oferecido pela ilustração sublinha o processo de superação do medo, pelo enfrentamento direto do objeto. $O$ momento culminante, que já nos encaminha para o clímax da história, é imediatamente posterior, indiciado novamente pela linguagem que reitera a palavra "medo" ("a Chapeuzinho Amarelo / foi perdendo aquele medo, / o medo do medo do medo / de um dia encontrar um LOBO") e "lobo" ("de um dia encontrar um LOBO. / Foi passando aquele medo / do medo que tinha do LOBO. / Foi ficando só com um pouco / de medo daquele lobo. / Depois acabou o medo"), que vai descendendo de sua alta potência ameaçadora (imageticamente representado pela caixa alta: "LOBO") para a caixa baixa "Iobo" ("e ela ficou só com o lobo"). Nesse último verso, ficar só com o lobo é ficar tanto a sós com o lobo como também ficar somente o lobo, substantivo masculino comum, reles lobo). O medo que diminui até desaparecer segue reforçado pela paronomásia: "porque um lobo, tirado o medo, / é um arremedo de lobo". As rimas também adquirem um sentido maior entre: "Ficou mesmo envergonhado, / [...] / Lobo pelado", ou ainda em "triste, murcho e branco-azedo, / porque 
um lobo tirado o medo": coincidência de acento e conjunto fônico, como a produzir um parentesco linguístico-semântico entre as palavras.

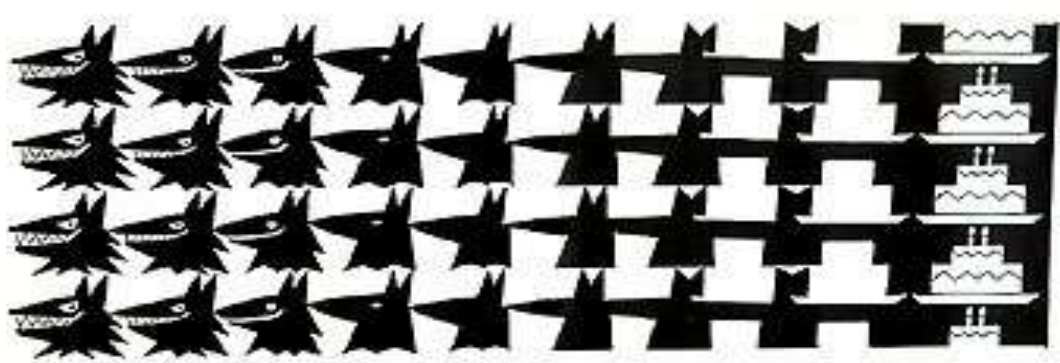

LO BO LO BO LO BO LO BO LO BO LO BO LO BO LO BO LO BO LO

(idem: s.p.)

O processo paralelístico do ponto de vista fônico, como vimos, encontra uma correspondência no plano paronomástico no momento em que a superação do medo pela personagem de Chapeuzinho Amarelo se realiza. Após a indiferença da menina face à figura do lobo já dissolvida no enunciado "Lobo pelado", ou seja, sem a pele do Lobo, sem a fantasia ou capa da maldade, já desacreditada pela menina, o Lobo se pôs a reivindicar sua identidade, porém, sem sucesso.

\footnotetext{
Ele então gritou bem forte

Aquele seu nome de LOBO

Umas vinte e cinco vezes,

Que era pro medo ir voltando

E a menininha saber

Com quem não estava falando: (idem: s.p.)
}

A repetição do módulo LO-BO insistentemente constrói o seu oposto BO-LO: é pelo viés da linguagem que o Lobo é devorado. Metamorfose visual pelo jogo gráfico das sílabas. Vale acentuar nesse momento a realização do ato tal qual a ilustração de Ziraldo apresenta. Pela referência ao artista holandês Maurits Cornelis Escher (1898-1972), Ziraldo dá movimento visual ao processo de metamorfose num jogo figura e fundo, em que a imagem do focinho do lobo vai perdendo seus caracteres de figura e fornecendo ao olhar o que estava oculto no fundo. O perfil do bolo vai, então, adquirindo presença de figura, deixando a do lobo como fundo. O lúdico do processo é adensado pela brincadeira infantil que 
adentra a história pela voz da menina: “'Para assim! Agora! Já! / Do jeito que você tá!'” (idem: s.p.). Eis o elemento mágico da palavra a transformar o outro: puro encantamento e belo castigo para um Lobo mau... O processo de rebaixamento se define e o medo é pulverizado.

O reconto aqui transcria a história legada pela tradição e atualiza pelo poético o traço emancipatório da personagem. Chapeuzinho Amarelo torna-se, ao final, ativa e sociável com todos. Sabe agora como enfrentar os medos: transforma-os "em companheiro / cada medo que ela tinha: / o raio virou orrái, / barata é tabará, / a bruxa virou xabru / e o diabo é bodiá" (idem: s.p.).

Eis o elemento pedagógico que leva "ao verdadeiro diálogo com o ser literário infantil" (Palo / Oliveira 1992: 14), privilegia, como assevera as autoras, o uso poético da informação. Em outras palavras,

ao uso passivo e consumista se sobrepõe um uso que implica atividade efetiva da mente receptora, sujeito das conexões que cria e reconstrói em cumplicidade com seu outro - o livro -, também ele renascendo a cada instante em que se vê em processo de leitura. (ibidem)

\section{A reescrita: um (des)a-fiar da própria história?}

Escrever é um desafio, já se sabe, pois é um desfiar de fios, aqueles que o tempo e a história nos fornecem como um legado. É inserir-se nesse novelo e buscar o novo no velho (eco que faço aqui do poema "ovonovelo", de Augusto de Campos), ou seja, nas histórias já contadas buscar aquilo que ainda pode surpreender. As histórias orais, compartilhadas, as escritas, ou as lidas pela voz do outro e depois por nossa própria, ou mesmo as que para cujas imagens apenas olhávamos, quando crianças, sem domínio dos signos da escrita, essas histórias espiavam para dentro do universo das histórias encantadas. E, por dentro da gente, procuravam em nosso mundo interior as tranças que também armávamos nas leituras que nos vinham do mundo que descobríamos quando crianças. A cada história lida, um antes de nós mesmos vivia a procurar os fios da memória e eis que, ao desmancharmo-los com o tempo, encontramo-nos revivendo e reinventando o mundo a nossa volta. Esse desfiar fios e 
destrançar as tranças encontra na palavra encantada da poesia o seu lugar de desfazimento e de recriação contínua.

A poesia adentra o espaço narrativo em O Menino que Olhava pra Dentro, ao circunscrever o mundo dos sonhos e da fantasia vividos pelo personagem intensamente; em Chapeuzinho Amarelo, a poesia ergue-se como o próprio fio do narrar, rearranjando as palavras no seu viés lúdico que prima por aproximar os elementos e promover a metamorfose entre eles.

Os contos de fadas e os contos maravilhosos reescrevem-se porque estão inseridos no mundo interior dos medos, dos assombros, das aventuras, dos heróis, dos obstáculos, dos desejos, das interdições, dos questionamentos, enfim, no mundo de nossa humanidade para qual buscamos respostas. Abstratas, as mãos cosem o impossível: a escrita novamente num movimento contínuo e curvilíneo, segue a costurar o legado de modo a desfazer a trança anterior. Ana Maria Machado faz justamente isso: performatiza pelo ato da escrita o desmanchar das tranças para compor e entrelaçar outros fios possíveis. Lucas é o autor de suas histórias maravilhosas e constrói um ritual, o de se encontrar no "para sempre" do mundo da imaginação, até o beijo que o despertará. Sem o ritual performático da maçã, símbolo e objeto mágico responsável por realizar o seu sonho, a trama não teria o mesmo tom poético. O texto se realiza como "passagem, travessia" (Barthes 2004), ou seja, é por ele e nele que vivemos a lição da necessidade de ficção e fantasia. Mostra-nos a narrativa de Lucas que a reescritura das histórias faz parte do universo infantil como uma busca constante de desfazer as tranças das histórias e procurar na autoria um novo elo com elas.

Chico Buarque recolhe da história clássica de Chapeuzinho Vermelho o elemento do medo do Lobo (figura arquetípica da devoração e do mal) para construir a figura de Chapeuzinho Amarelo, que, de "amarelada de medo", para a ser corajosa e ativa, por meio de um enfrentamento direto com o seu objeto. A experiência de alteridade, própria da poesia, realiza-se na palavra encantada: subversão pela alternância silábica do nome do objeto do temor: LO-BO > BO-LO. Metamorfose linguístico-visual e rebaixamento. Devoração crítica da história divulgada pelos Irmãos Grimm e recriada para um público leitor que não pode ser subestimado na sua capacidade de compreender-se a si e a seus medos e a emancipar-se por meio da linguagem. 


\section{NOTA}

\footnotetext{
${ }^{1}$ De relevante importância para a literatura brasileira, Ana Maria Machado é detentora de diversos prêmios nacionais e internacionais. Para citar alguns, foram, dentre eles, três Jabutis, o Prêmio Machado de Assis da Academia Brasileira de Letras (ABL), em 2001, pelo conjunto da obra e o Prêmio Machado de Assis da Biblioteca Nacional para romance, o Prêmio Casa de Las Americas, de Cuba, em 1980 e o Hans Christian Andersen, em 2000, pelo conjunto de sua obra infantil. Ocupa a cadeira número 1 da Academia Brasileira de Letras, da qual foi presidente entre 2011 e 2013.
}

\section{Bibliografia}

Barthes, Roland (2004), O Rumor da Língua, tradução de Mário Laranjeira, São Paulo, Martins Fontes.

Barros, Manoel de (1993), O livro das invencionices, Rio de Janeiro, Civilização Brasileira.

Buarque, Chico (2013), Chapeuzinho amarelo, Rio de Janeiro, José Olympio.

Callari, Alexandre (2012), Branca de Neve. Os Contos clássicos, São Paulo, Generale.

Candido, Antonio (2002), "A literatura como formação do homem", in Textos de intervenção, São Paulo, Duas Cidades, 77-92.

Fontela, Orides (2006), Poesia reunida [1969-1996], São Paulo, Cosac Naify, Rio de Janeiro, 7 letras.

Held, Jacqueline (1980), O Imaginário no Poder, São Paulo, Summus.

Machado, Ana Maria (1983), O Menino que Espiava pra Dentro, São Paulo, Global. 
Palo, Maria José / Maria Rosa Duarte de Oliveira (1992), Literatura Infantil. Voz de criança, São Paulo, Ática.

Steig, William (2008), Shrek!, New York, Square Fish.

-- (2010), Shrek!, tradução de Eduardo Brandão, São Paulo, Cia das Letrinhas.

Zumthor, Paul (2014), Performance, Recepção, Leitura, tradução de Jerusa Pires Ferreira e Suely Fenerich, São Paulo, Cosac Naify.

Susanna Busato é poeta e professora assistente-doutora de Poesia Brasileira e de Literatura Infantojuvenil, no Curso de Licenciatura em Letras e no Curso de Pedagogia, na Universidade Estadual Paulista "Júlio de Mesquita Filho, UNESP, São José do Rio Preto/SP. É Doutora em Letras (UNESP) e Mestre em Comunicação e Semiótica (PUC/SP). Atua na linha de pesquisa "Perspectivas Teóricas no Estudo da Literatura", com o projeto: "As performances da voz no espaço da poesia brasileira contemporânea". É líder do grupo de pesquisa GEP, Grupo de Estudos de Poesia, cadastrado no CNPq. É autora do livro de poemas Corpos em Cena (2013), Editora Patuá, com o qual foi finalista do 56ㅇ Prêmio Jabuti de Literatura, categoria poesia, em 2014. Tem poemas publicados em antologias e revistas eletrônicas, assim como em ensaios publicados em livro e em revistas acadêmicas e especializadas em literatura e arte. Participação como locutora da edição de voz dos poemas de sua autoria para o curtametragem Moinhos de Tempo, de Lucas Feitosa, em fevereiro de 2018, com patrocínio do Edital de Curtas Universitários do Canal Futura (2017/2018), em parceria com a Rede Globo e Associação Brasileira de Televisão Universitária (ABTU). 